Brit. J. vener. Dis. (1961), 37, 207.

\title{
TREATMENT OF GONORRHOEA WITH PHENETHICILLIN (BROXIL)*
}

\author{
BY
}

\author{
A. L. HILTON
}

Royal Infirmary, Doncaster

Many reports in the literature have described the oral treatment of acute gonorrhoea in males with penicillin. An intramuscular injection of penicillin requires some preparation, is less favoured by the recipient, and may possibly give rise to more severe sensitization reactions, but no advantage has yet been put forward to persuade venereologists to recommend the routine use of oral penicillin (King, 1959). Horne (1950), in an early paper describing the results of buffered calcium penicillin, thought that a patient could be relied upon to take only one further tablet after leaving the V.D. department.

In 1959 the Beecham Research Laboratories announced the preparation of a new synthetic penicillin, Broxil, the potassium salt of $6-(\alpha-$ phenoxypropionamido) penicillanic acid (approved name Phenethicillin). The impetus for a clinical trial was given by the claim that Broxil gave penicillin blood levels twice as high as penicillin $\mathrm{V}$ and at least equal to intramuscular injections of penicillin G. Table I shows random serum levels in nine patients after taking 0.5 or $1 \mathrm{~g}$. Phenethicillin.

* Short paper read to M.S.S.V.D. on November 25, 1960.
These results confirmed the work of Knudsen and Rolinson (1959), who have shown that little or no penicillin is detectable after 6 hours.

When four patients with acute gonorrhoea had failed to respond to $0.5 \mathrm{~g}$. Phenethicillin 6-hourly for 24 hours, larger amounts $(1 \mathrm{~g}$. to be repeated after 6 hours and $2 \mathrm{~g}$. in a single dose) were given to 66 male patients attending the Doncaster clinic. The present communication describes the results of exposing the patient to what was hoped would be a high antibacterial dosage in a minimum time, for it is well recognized that there are grave risks inherent in prolonged oral therapy when a patient, through either forgetfulness or complacency, neglects to complete his course of treatment.

\section{Methods and Materials}

All the patients had acute uncomplicated gonorrhoea. The smear diagnosis was invariably confirmed by culture. An attempt was made to exclude patients whose previous history or occupation suggested that they would not attend for regular

TABLE I

SERUM CONCENTRATIONS AFTER PHENETHICILLIN

\begin{tabular}{|c|c|c|c|c|c|c|c|c|c|}
\hline \multirow{2}{*}{ Patient No. } & \multirow{2}{*}{ Dose (mg.) } & \multicolumn{8}{|c|}{ Serum Concentrations ( $\mu \mathrm{g} . / \mathrm{ml})}$. \\
\hline & & $1 \mathrm{hr}$ & $2 \mathrm{hrs}$ & $3 \mathrm{hrs}$ & $3 \frac{1}{2} \mathrm{hrs}$ & $4 \mathrm{hrs}$ & $5 \mathrm{hrs}$ & $6 \mathrm{hrs}$ & $7 \mathrm{hrs}$ \\
\hline 1 & 500 & 7 & & & & 0.9 & & & \\
\hline 2 & 500 & & 1 & & & 0.06 & & & \\
\hline 3 & 500 & & & 1.9 & & & & & \\
\hline 4 & 500 & & & & & & & & Nil \\
\hline 5 & 500 6-hrly +3 & & 0.9 & & & & & & \\
\hline 6 & 500 6-hrly + 4 & & & & & & $0 \cdot 25$ & & \\
\hline 7 & 1,000 & & & & $1 \cdot 8$ & & & 0.25 & \\
\hline 8 & 1,000 & & & & & $0 \cdot 25$ & & Nil & \\
\hline 9 & 1,000 & & & & & $0 \cdot 2$ & & Nil & \\
\hline
\end{tabular}


surveillance. Treatment consisted of $1 \mathrm{~g}$. Phenethicillin given in the clinic and another similar dose to be taken 6 hours later. More recently a smaller number of patients were given one single dose of $2 \mathrm{~g}$. Phenethicillin. Patients were encouraged to return for an early morning smear the following day or as soon as possible. Apparent successes were seen twice or thrice in the week following therapy and then less frequently for 6 months. Blood was taken for a Wassermann reaction and Kahn test before treatment, and 3 and 6 months later in order to screen a possible coincidental syphilitic infection.

Penicillin concentrations were determined by doubling dilutions of the serum under investigation and of a standard Phenethicillin solution, the diluent being bovine plasma albumen. Sarcina lutea was used as the test organism. Sensitivity tests were performed on solid media. Standard absorbent disks were impregnated with known strengths of Phenethicillin and Benzyl penicillin and deep-frozen until required. The disks were placed on blood agar plates sown with inocula from untreated cases of acute gonorrhoea. No effort was made to control the density or purity of the inocula or the thickness of the media, or to measure the inhibitory zones.

\section{Results}

Fifty-four men were given $2 \mathrm{~g}$. Phenethicillin in a divided dose. There were 23 failures and 31 apparent successes. Twenty-one out of the 23 failures showed gonococci in their smears, up to the fourth day following treatment. One suspected failure had no complaint or visible urethral discharge on the second and fifth post-treatment days when a centrifuged specimen of urine yielded pus cells but a negative culture. Positive results were eventually obtained on the seventh day in an early morning smear. Another carrier had a temporary improvement for only 3 days yet his smears and cultures 4 and 6 hours after treatment were negative. Most of the failures were then given 1.2 mega units PAM with Probenecid (Hilton, 1959) with good effect.

One patient was treated as a case of concomitant non-gonococcal urethritis, and the remaining thirty were apparent successes. One defaulted immediately; two early defaulters had negative smears after treatment; 83.3 per cent. were followed for 2 weeks, 66.6 per cent. for a month, and 33.3 per cent. for 2 months. Two cases were considered to be reinfections occurring 4 and 6 weeks after treatment. 21 of 43 white patients were failures against only two out of ten coloured patients.

The disk sensitivity tests are recognized to be no substitute for more refined methods, but the relatively simple tests described were useful as a screening procedure. There was good correlation between the results and the clinical outcome, 18 per cent. of the patients with the strains most sensitive to Broxil being failures, contrasted with a failure rate of 80 per cent. in patients with the least sensitive strains.

As there were unsatisfactory results following a double dose it was decided to try a large single dose of $2 \mathrm{~g}$. Phenethicillin. Table II shows that Phenethicillin was well absorbed. The lowest levels occurred in a patient who had a meal within one hour of taking the tablets. The serum estimations did not vary with the weight of the men.

TABLE II

MEAN SERUM CONCENTRATIONS AFTER $2 \mathrm{~g}$. PHENETHICILLIN

\begin{tabular}{c|c|c|c|c|}
\hline \multirow{2}{*}{$\begin{array}{c}\text { No. of } \\
\text { Patients }\end{array}$} & $\begin{array}{c}\text { Average Time after } \\
\text { Meals (hrs) }\end{array}$ & \multicolumn{2}{|c|}{ Serum Concentrations $(\mu \mathrm{g} . / \mathrm{ml})}$. \\
\cline { 3 - 5 } & 4 & $30 \mathrm{~min}$. & $45 \mathrm{~min}$. & $60 \mathrm{~min}$. \\
\hline 7 & 4 & $7 \cdot 1$ & $26 \cdot 2$ & $26 \cdot 6$ \\
\hline
\end{tabular}

Twelve patients were treated and seven continued to have gonococci in their smears 1 to 3 days after treatment, a failure rate of $58 \cdot 3$ per cent. One of them had already failed to respond to intramuscular penicillin given abroad. One of the apparent successes was only followed for $2 \frac{1}{2}$ weeks the remainder for over 5 weeks. The complete results are shown in Table III.

TABLE III

RESULTS OF TREATMENT WITH PHENETHICILLIN

\begin{tabular}{c|c|c|c|c}
\hline Dose & $\begin{array}{c}\text { No. of Cases } \\
\text { Treated }\end{array}$ & $\begin{array}{c}\text { No. of Cases } \\
\text { followed for } \\
\text { 2 weeks }\end{array}$ & \multicolumn{2}{|c}{ Failures } \\
\cline { 2 - 5 } $\begin{array}{c}\text { 1 go. repeated } \\
\text { in 6 hrs }\end{array}$ & 54 & 49 & $\begin{array}{c}\text { Per } \\
\text { cent. }\end{array}$ \\
\hline $2 \mathrm{~g}$. & 12 & 12 & $46 \cdot 9$ \\
\hline Total & 66 & 61 & 30 & $58 \cdot 3$ \\
\hline
\end{tabular}

The main side-effect was severe diarrhoea for 2 days in two patients, but a few complained of diarrhoea of a mild and transient character.

\section{Discussion}

Willcox (1958) treated 33 white patients with 2 or 3 million units phenoxymethyl penicillin (penicillin V) in two doses separated by a 6-hr. interval or in a single dose with complete success, and he had a 28.6 per cent. failure rate in 49 coloured patients satisfactorily followed. Three million units penicillin $\mathrm{V}$ are approximately equivalent to $1.8 \mathrm{~g}$. Broxil. 
Thurman (1958) gave a single dose of $750 \mathrm{mg}$. improved potassium penicillin $\mathrm{V}$ to eighteen patients, and claimed that 66.6 per cent. were completely cured clinically within 48 hours.

It was disappointing to find that Phenethicillin was less effective than either of these two drugs, but quite recently Garrod (1960) has provided evidence which shows that these poor results might well have been expected. He measured the minimum concentrations of penicillin G, penicillin V, Broxil, and B.R.L. 1241 ("Celbenin") required to inhibit seventeen strains of gonococci. Most of the strains were more sensitive to penicillin $G$ than to penicillin $\mathrm{V}$, "Celbenin", or Broxil, in that order. There was a sixteen-fold difference between the activity of penicillin $\mathbf{G}$ and that of Broxil.

The results of the present trial indicate that a new oral penicillin capable of completely eradicating the gonococcus in one or two doses is still awaited.

\section{Summary}

Sixty-six patients with acute gonorrhoea were treated with $2 \mathrm{~g}$. Phenethicillin (Broxil), 54 had a divided dose, twelve had a single dose. The failure rate in those patients followed for 2 weeks was 46.9 and 58.3 per cent. respectively.

A comparison of the results of other clinical trials and of tests in vitro with those in this series suggests that Phenethicillin is probably the least effective of the oral penicillins at present available for the treatment of acute gonorrhoea.

Once again I should like to acknowledge the help given by Mr. John Cliff, technician, and Dr. Henry Lederer, director of the Pathology Department.

I am grateful to Beecham Research Laboratories Ltd. for the supply of Broxil.

\section{REFERENCES}

Garrod, L. P. (1960), Brit. med. J., 2, 1695.

Hilton, A. L. (1959). Brit. J. vener. Dis., 35, 249.

Horne, G. O. (1960). Ibid., 26, 23.

King, A. J. (1959). Brit. med. J., 2, 1396.

Knudsen, E. T., and Rolinson, G. N. (1959). Lancet, 2, 1105 .

Thurman, J. R. (1959). Antibiot. Med., 6, 295.

Willcox, R. R. (1958). Brit. J. vener. Dis., 34, 118.

Traitement de la gonorrhée par la phénéthicilline (Broxil)

\section{RÉSUMÉ}

2 g. phénéthicilline (Broxil) furent administrés à 66 hommes atteints de gonorrhée aiguë; 54 reçurent cette dose en deux fois, et 12 la reçurent en une seule fois. Le pourcentage des échecs chez les malades suivis, pendant deux semaines fut $46,9 \%$ et $58,3 \%$ respectivement.

La comparaison entre les résultats d'autres essais cliniques, des tests in vitro et ceux de cette série suggère que la phénéthicilline est probablement la moins efficace des pénicillines orales dont on dispose à l'heure actuelle pour le traitement de la gonorrhée aiguë. 